\title{
Lowermost Ordovician (basal Tremadoc) radiolarians from the Little Port Complex, western Newfoundland
}

\author{
JONATHAN C. AITCHISON*†, PETER G. FLOOD \& JOHN MALPAS* \\ * Department of Earth Sciences, University of Hong Kong, Pokfulam Road, Hong Kong, China \\ ¥Department of Geology and Geophysics, University of New England, Armidale, NSW 2351, Australia
}

(Received 29 April 1997; accepted 6 November 1997)

\begin{abstract}
Lowermost Ordovician (basal Tremadoc) cherts from the Little Port Complex, western Newfoundland, contain a distinctive, moderately well-preserved, radiolarian assemblage. The fauna differs from those reported from the Arenig, suggesting that some of the earliest radiolarian forms may have biostratigraphic potential. The abundance of radiolarians in chert and the ease with which they can be extracted suggest that they are a potentially valuable tool for use in investigations of the timing and development of early Palaeozoic orogenic systems. A previously undescribed radiolarian Beothuka terranova sp. nov., belonging to a new genus Beothuka gen. nov. and of uncertain higher-level affinity is formalized herein.
\end{abstract}

\section{Introduction}

Radiolarians range through the Phanerozoic, and the huge increase in the number of studies of this microfossil group over the past few decades has resulted in the development of a detailed radiolarian biostratigraphy back as far as the Upper Palaeozoic. As they are commonly the only fossils found in abundance in deep water marine rocks such as chert, which together with turbiditic sandstones, characterizes ancient subduction zones, their biostratigraphy is of particular importance. Application of radiolarian biostratigraphy to previously undated rocks in Upper Palaeozoic and Mesozoic strata in ancient subduction complexes has revolutionized understanding of orogenic zones worldwide (Aitchison \& Murchey, 1992). However, the utility of older members of this fossil group has not yet been realized because of a lack of knowledge of diagnostic, readily identifiable, distinctive faunas in the Lower Palaeozoic. Because ancient zones of plate convergence such as the massive early Palaeozoic orogenic systems of central Asia are beginning to attract more comprehensive geological investigations, the potential contribution of a detailed radiolarian biostratigraphy is considerable. The oldest described material that is indisputably radiolarian is from Ordovician rocks of the Ballantrae ophiolite in Scotland (Aitchison, 1998). Radiolarian-bearing rocks at this locality are biostratigraphically correlated with the mid-Arenig (Stone \& Rushton, 1983; Rushton et al. 1986). A similar fauna is known from slightly younger strata in Spitsbergen (Fortey \& Holdsworth, 1971) and Kazakhstan (Nazarov $\&$ Popov, 1980). While reports of possible radiolarian material from the Cambrian exist (Bengston, 1986; Nazarov, 1973; White, 1986), the taxonomic assignment

$\dagger$ Author for correspondence: jona@hku.hk of most of this material remains dubious and the fossils are best described as being the remains of organisms with siliceous skeletons that bear some resemblance to radiolarians. Morphological diversity appears to be extremely low with the most convincingly radiolarian-like forms having simple spherical, porous skeletons. Recent work (Dong, Knoll \& Lipps, 1997) indicates that recognizable radiolarian material may exist within Cambrian strata.

Ordovician radiolarians are not particularly well known and the few existing detailed descriptions of faunas are mainly from relatively shallow-water lithologies in which other fossil groups are abundant and where taphonomic conditions have led to unusually good preservation (Fortey \& Holdsworth, 1971; Noble \& Aitchison 1995; Renz, 1990a,b; Wang, 1993; Webby \& Blom, 1986). Nazarov (1988) recognized three longranging assemblages in samples collected from a wide variety of lithologies of Ordovician age. More recently, moderately well-preserved, taxonomically diverse, Middle Ordovician material has been described from Australia (Iwata et al. 1995; Nazarov, 1988; Umeda, Goto \& Ishiga, 1992), China (Li, 1995), and Scotland (Aitchison, 1998). Ordovician faunas from rocks older than Arenig have not previously been described.

As a result of our recent examination of lowermost Ordovician cherts from the Little Port Complex in western Newfoundland, the first description of a Tremadoc fauna can be presented. Although of low diversity, the fauna contains readily identifiable robust forms, which are apparently short-ranging and clearly have biostratigraphic potential. Material was recovered from red ribbon-bedded cherts which are intimately associated with pillow basalts. This 'ophiolitic' rock association is common amongst the deep marine lithologies found within orogenic systems. 


\section{Regional setting}

The Humber Arm Allochthon of western Newfoundland consists of a number of stacked thrust slice assemblages and intervening melanges, the two highest of which are known as the Bay of Islands Complex and the Little Port Complex. The Bay of Islands Complex represents a piece of Lower Palaeozoic oceanic lithosphere that was obducted westward over the autochthonous Cambro-Ordovician continental margin of North America during the Taconian orogeny (Church \& Stevens, 1971; Williams, 1975; Malpas \& Stevens, 1977). It displays a complete ophiolite stratigraphy. The Little Port Complex was formally described by Williams (1975) as the structural slice immediately below the Bay of Islands Complex and is now considered as representative of an arc complex older than the Bay of Islands Complex on the basis of structural geology, and trace element and isotope geochemistry (Williams \& Malpas, 1972; Williams \& Cawood, 1989; Jenner et al. 1991; Cawood \& Suhr, 1992). This arc apparently rifted during a phase of suprasubduction zone spreading associated with the generation of the Bay of Islands Complex. Jenner et al. (1991) report a series of age dates obtained for both complexes. In summary, the most reliable $\mathrm{U} / \mathrm{Pb}$ age data suggest that with an age of 479-489 Ma (Arenig) the Bay of Islands Complex is significantly younger than the Little Port Complex ( $\left.505_{-2}^{+3} \mathrm{Ma}\right)$. According to the time scale of Harland et al. (1989) this corresponds to an early Tremadoc age, whereas more recent studies of early Palaeozoic geochronology (Tucker \& McKerrow, 1995) interpolate the base of the Ordovician to be at c. $495 \mathrm{Ma}$.

In the vicinity of Winter House Brook the Little Port Complex is locally reduced to melange amongst which there are large tectonic inclusions of pillow basalt and red ribbon-bedded chert containing moderately wellpreserved radiolarians. Red cherts were collected from a locality on the opposite side of the road from the Winter House Brook Lookout (Lat. $49^{\circ} 25^{\prime} 34^{\prime \prime} \mathrm{N}$, Long. $058^{\circ} 08^{\prime}$ $\left.59^{\prime \prime} \mathrm{W}\right)$ with several samples producing moderately wellpreserved radiolarians. Although the precise age of the sample is unknown, conodonts occurring together with the radiolarians include a possible specimen of Cordylodus lindstromi indicative of a basal Tremadoc age (Miller, 1988; Nicoll, 1990).

\section{Radiolarian faunas}

Moderately well-preserved radiolarian faunas were extracted from cherts using standard HF acid leaching techniques (Pessagno \& Newport, 1972). The fauna contains both spherical (spumellarian) and bi-polar forms. As is commonly the case, the spherical forms are rather nondescript and even if they were once distinctive, the uniqueness of individual taxa has deteriorated through post-burial geological processes. Nevertheless, nonspherical forms which are both distinctive and different occur at each locality. A previously undescribed bi-polar form dominates the Little Port Complex Tremadoc fauna. Other material in the fauna includes abundant, but poorly preserved, sphaerellarians which may possibly be inaniguttids. All specimens described in this paper are assigned HKUDES collection numbers and are housed in the Department of Earth Sciences, University of Hong Kong.

\section{Discussion}

The Little Port Complex fauna is dominated by a bi-polar form (Fig. 1) which is accompanied by various sphaerellarians. The composition of the western Newfoundland radiolarian fauna differs from younger material described from the Lower Ordovician (upper Arenig) of Kazakhstan (Nazarov, Popov \& Apollonov, 1975) and Scotland (mid-Arenig: Aitchison, 1998) which is assigned to the Haplentactinia armillata-Proventocitum procerulum assemblage of Nazarov (1988). The distinctive conical spongy form of radiolarian which occurs within the Scottish Arenig material (Aitchison, 1998) was not found in the Little Port Complex samples but is present in younger Arenig strata of the nearby Cow Head Group (W. Iams, pers. comm; Aitchison, pers. obs.). The Little Port Complex fauna appears to define a distinctly different and older radiolarian assemblage than any presently known. The lower limit of this new assemblage is yet to be determined.

The discovery of distinctive Lower Palaeozoic radiolarian faunas has implications for wider geological investigations. Early Palaeozoic orogenic zones are extensive (eastern North America, Caledonides, eastern Australia and Central Asia) and without good age control their tectonic histories cannot be accurately constrained. If biostratigraphic potential can be demonstrated for Lower Palaeozoic radiolarians then considerable further study is clearly warranted. The radiolarians described herein were recovered from ribbon-bedded cherts associated with ophiolitic pillow lavas. Paradoxically, despite the initial pre-lithification abundance of radiolarian tests in sediment, these rocks often have the poorest recovery rates for readily identifiable, and therefore potentially biostratigraphically useful, material. The presence of morphologically distinctive radiolarians capable of recognition even after they have experienced diagenesis and low-grade metamorphic conditions is a prerequisite for the establishment of a robust biostratigraphic zonation that can be utilized by tectonostratigraphers working in orogenic zones. Radiolarian-rich lithologies are as abundant in early Palaeozoic orogenic zones as they are in younger orogenic systems elsewhere, and most other fossil groups are poorly represented, poorly preserved, or inadequate in terms of their biostratigraphic resolution in these rocks. Many of the radially symmetrical, spumellarian radiolarian taxa which are common in the Lower Palaeozoic are not useful for biostratigraphic purposes. This is because their identification often requires recognition of internal detail that is commonly masked by secondary mineral infilling or may have been removed by dissolution. When viewed externally, many spumellarian taxa look alike and cannot be discriminated. In Upper Palaeozoic rocks, radiolarians with distinctive external morphologies, particularly bilaterally 


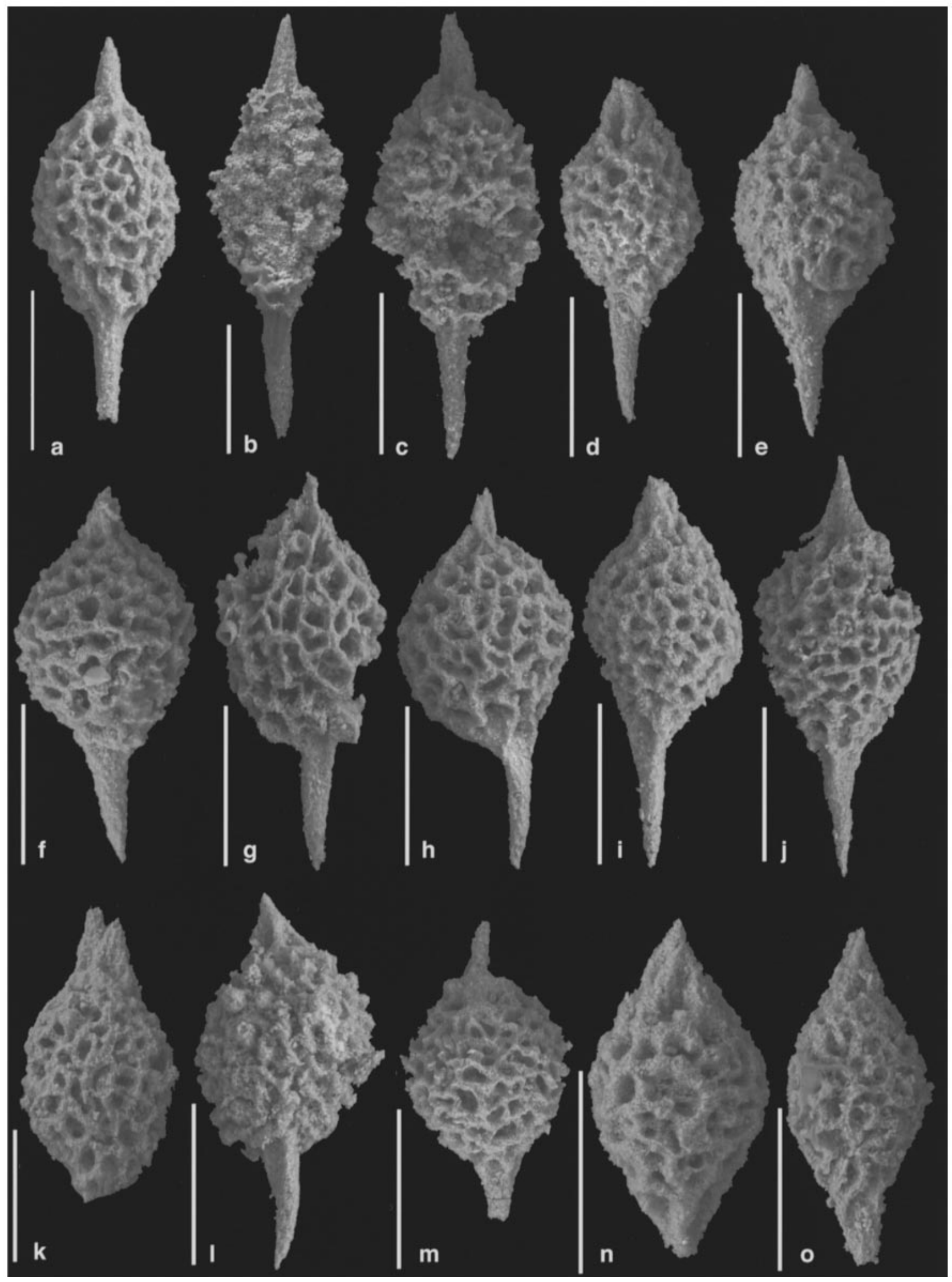

Figure 1. Lower Ordovician (Tremadoc) radiolarians from the Little Port Complex, Winter House Brook Lookout (Lat. 49 $25^{\prime} 34^{\prime \prime} \mathrm{N}$, Long. $\left.058^{\circ} 08^{\prime} 59^{\prime \prime} \mathrm{W}\right)$, western Newfoundland. All scale bars are $100 \mu \mathrm{m}$. (a-o) Beothuka terranova sp. nov. curated sequentially as HKUDES 97/0001-0015. (Holotype Fig. 1a, specimen HKUDES 97/0001; all other figured specimens are paratypes). 


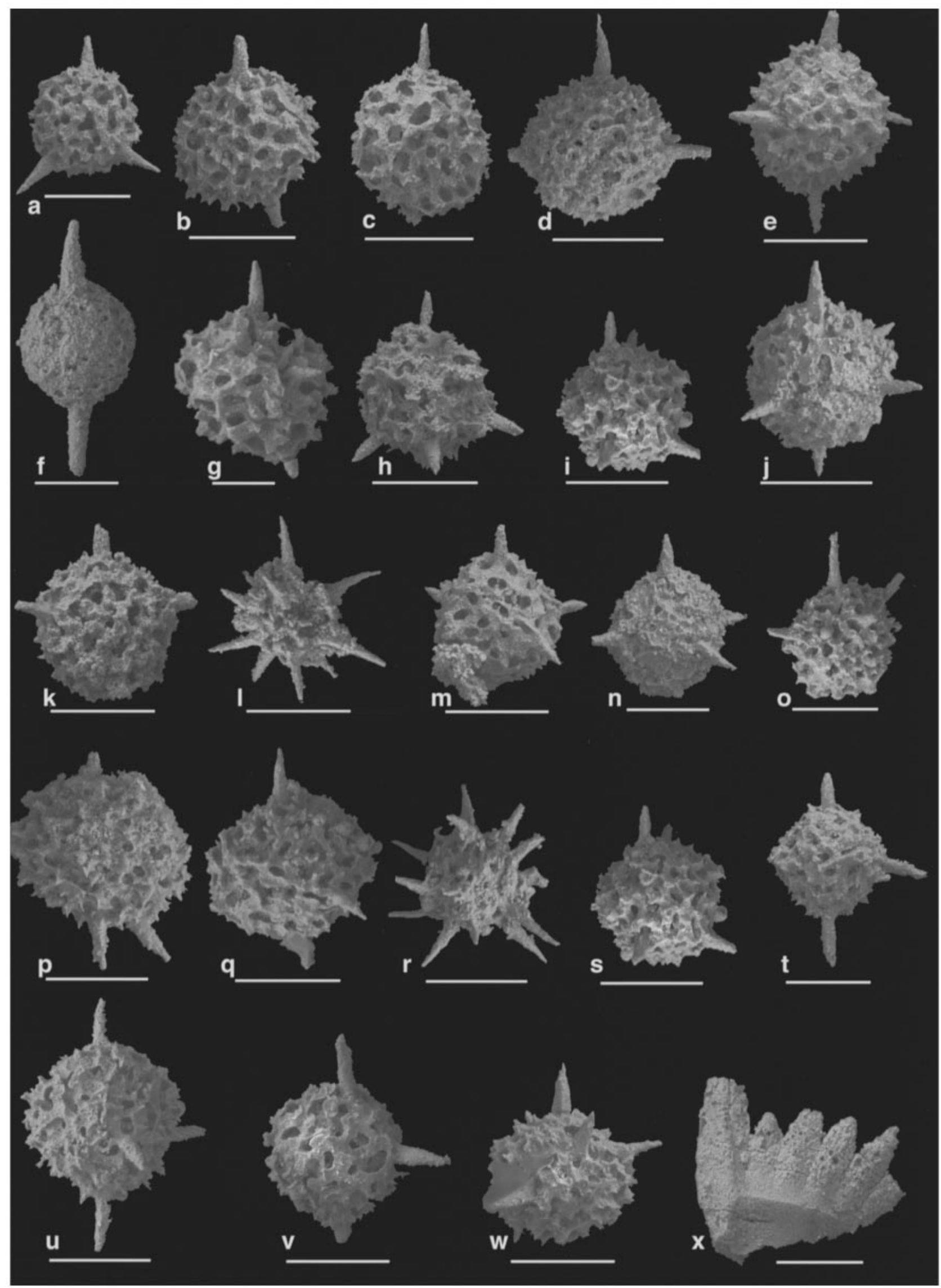

Figure 2. Lower Ordovician (Tremadoc) radiolarians and one conodont specimen from the Little Port Complex, Winter House Brook Lookout (Lat. $49^{\circ} 25^{\prime} 34^{\prime \prime} \mathrm{N}$, Long. $058^{\circ} 08^{\prime} 59^{\prime \prime} \mathrm{W}$ ), western Newfoundland. All scale bars are $100 \mu \mathrm{m}$. (a) sphaerellarian gen. et. sp. indet A HKUDES 97/00016; (b) sphaerellarian gen. et. sp. indet A HKUDES 97/00017; (c) sphaerellarian gen. et. sp. indet A HKUDES 
symmetrical taxa, have proved most useful in the establishment of biostratigraphic zonations that can be widely applied (Holdsworth \& Jones, 1980). It appears that similar circumstances may exist within Lower Palaeozoic strata and a robust biostratigraphy may be achievable. It is suggested, however, that radiolarian palaeontologists should describe all elements of faunas they study as full description of faunas may eventually lead to important discoveries about provinciality, productivity of watermasses, early evolution of protozoans and other topics.

\section{Systematic description}

Subclass RADIOLARIA Müller, 1858

Order POLYCYSTIDA Ehrenberg, 1838

Suborder Incertae sedis

Family Incertae sedis

Beothuka gen. nov.

Type species Beothuka terranova sp. nov.

Etymology. Named for the Beothuk who were the aboriginal inhabitants of Newfoundland when European settlers first arrived.

Diagnosis. Ellipsoidal radiolarian with thick latticed to coarsely porous cortical shell. Robust bi-polar rodded spines tapering to a point.

Discussion. Internal structure of specimens assigned to this genus remains uncertain. On broken specimens, such as Figure 1c which appears to be hollow, there is no clear hint of any concentric inner shells. Spines do not appear to continue through the shell, rather they originate at the outer shell layer. However, the possibility that spines were linked through a thin, weakly developed spicular rod with poor preservation potential cannot be excluded.

This form is superficially similar to bi-polar radiolarians seen later in the Silurian (Noble, 1994) but is considered to be phylogenetically distinctive with no similar forms known from intervening faunas. The presence of a single thick latticed, ellipsoidal cortical shell with bi-polar rodded spines is distinctive. On specimens deliberately broken in order to examine their internal structure, no concentric spongy layered structure such as that which is present in the Silurian forms Pseudospongoprunum Wakamatsu was observable. Praespongocoelia Noble, another Silurian taxon is described as having a finer spongy meshwork than
Table 1. Dimensions of Beothuka terranova sp. nov.

\begin{tabular}{lrcc}
\hline Measurements in $\mu \mathrm{m}$ & Average & Range & Number of specimens \\
\hline Length of apical spine & 30 & $16-48$ & 20 \\
Length of basal spine & 75 & $50-102$ & 20 \\
Long axis of shell & 146 & $113-176$ & 20 \\
Width of shell & 103 & $89-116$ & 20 \\
\hline
\end{tabular}

Pseudospongoprunum Wakamatsu. This kind of structure also differs considerably from the thick latticed to coarsely porous cortical shell of Beothuka gen. nov.

The genus Beothuka is currently placed within the grouping 'incertae sedis' as it cannot easily be placed within any presently described radiolarian suborders known from the Ordovician. Phylogenetic links, if any, to younger radiolarian suborders are unknown. Similar forms are unknown from both older faunas from the Cambrian (Dong, Knoll \& Lipps, 1997) and from slightly younger Ordovician strata (Aitchison, 1998).

\section{Beothuka terranova sp. nov.}

Figure 1a-o

Etymology. Terra Nova, the Latin for Newfoundland.

Holotype. HKUDES 97/0001 (Fig. 1a) from red ribbonbedded chert of the Little Port Complex at Winter House Brook Lookout (Lat. $49^{\circ} 25^{\prime} 34^{\prime \prime} \mathrm{N}$, Long. 058 $08^{\prime}$ $\left.59^{\prime \prime} \mathrm{W}\right)$.

Paratypes. HKUDES 97/0002-97/0015 (Fig. 1b-o) from red ribbon-bedded chert at the type locality.

Diagnosis. Thickly latticed or coarsely porous ellipsoidal cortical shell. Approximately 30 pores are present on each hemisphere. Bi-polar rodded spines which taper over their entire length to a point. One spine (basal spine) is commonly longer than the other. On some specimens (e.g. HKUDES 97/0011, Fig. 1k) the shorter (apical) spine may be split into two short spines. Basal portions of spines are commonly grooved (e.g. Fig. 1a, h, i).

Description. Basal (longer) spine often appears to be slightly offset from the polar axis and some specimens thus have an asymmetrical appearance.

\section{Dimensions. See Table 1.}

Discussion. See that for genus.

97/00018; (d) sphaerellarian gen. et. sp. indet A HKUDES 97/00019; (e) sphaerellarian gen. et. sp. indet A HKUDES 97/00020; (f) unidentified bipolar spherical radiolarian HKUDES 97/00021; (g) sphaerellarian gen. et. sp. indet A HKUDES 97/00022; (h) sphaerellarian gen. et. sp. indet A HKUDES 97/00023; (i) sphaerellarian gen. et. sp. indet A HKUDES 97/00024; (j) sphaerellarian gen. et. sp. indet A HKUDES 97/00025; (k) sphaerellarian gen. et. sp. indet A HKUDES 97/00026; (1) sphaerellarian gen. et. sp. indet B HKUDES 97/00027; (m) sphaerellarian gen. et. sp. indet A HKUDES 97/00028; (n) sphaerellarian gen. et. sp. indet A HKUDES 97/00029; (o) sphaerellarian gen. et. sp. indet A HKUDES 97/00030; (p) sphaerellarian gen. et. sp. indet A HKUDES 97/00031; (q) sphaerellarian gen. et. sp. indet A HKUDES 97/00032; (r) sphaerellarian gen. et. sp. indet B HKUDES 97/00033; (s) sphaerellarian gen. et. sp. indet A HKUDES 97/00034; (t) sphaerellarian gen. et. sp. indet A HKUDES 97/00035; (u) sphaerellarian gen. et. sp. indet A HKUDES 97/00036; (v) sphaerellarian gen. et. sp. indet A HKUDES 97/00037; (w) sphaerellarian gen. et. sp. indet A HKUDES 97/00038; (x) conodont element Cordylodus lindstromi Druce \& Jones HKUDES 97/00039. 
Material. Abundant in samples collected from red ribbonbedded chert of the Little Port Complex at Winter House Brook Lookout (Lat. $49^{\circ} 25^{\prime} 34^{\prime \prime} \mathrm{N}$, Long. $058^{\circ} 08^{\prime} 59^{\prime \prime} \mathrm{W}$ ).

Age and distribution. Lower Ordovician (basal Tremadoc), Little Port Complex, western Newfoundland, so far as is known.

Family INANIGUTTIDAE Nazarov \& Ormiston, 1984; emend Noble, 1994

sphaerellarian gen. et sp. indet A

Figure $2 \mathrm{a}-\mathrm{e}, \mathrm{g}-\mathrm{k}, \mathrm{m}-\mathrm{q}, \mathrm{s}-\mathrm{w}$

Description. Poorly preserved specimens with irregularly porous cortical shell. Approximately six short rodded tapering primary spines.

Remarks. It is suspected that both sphaerellarian gen. et. sp. indet A and sphaerellarian gen. et. sp. indet B are inanigittids. Although the specimens are distinctive, preservation is not sufficient to permit determination of detailed taxonomic affinity. Specimens illustrated have significantly fewer spines than specimens assigned to sphaerellarian gen. et. sp. indet B.

Material. Abundant in samples collected from red ribbonbedded chert of the Little Port Complex at Winter House Brook Lookout (Lat. $49^{\circ} 25^{\prime} 34^{\prime \prime} \mathrm{N}$, Long. 058 $08^{\prime}$ $\left.59^{\prime \prime} \mathrm{W}\right)$.

Age and distribution. Lower Ordovician (basal Tremadoc), Little Port Complex, western Newfoundland, so far as is known.

sphaerellarian gen. et sp. indet B

Figure 21, r

Description. Poorly preserved specimens with irregularly porous cortical shell. Numerous (approximately 10 per hemisphere) short rodded tapering primary spines.

Remarks. As with sphaerellarian gen. et. sp. indet A the specimens are distinctive but preservation is not sufficient to allow determination of detailed taxonomic affinity.

Material. Abundant in samples collected from red ribbonbedded chert of the Little Port Complex at Winter House

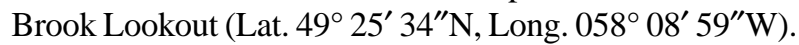

Age and distribution. Lower Ordovician (basal Tremadoc), Little Port Complex, western Newfoundland, so far as is known.

Acknowledgements. Lower Palaeozoic radiolarian biostratigraphy research was supported by the University of Sydney ARC small grants scheme and is now funded by the HKU CRGC. We thank Ms C. James of the University of Sydney for help with the initial acid leaching of some of the chert samples examined in this study. We also thank reviewers Fortey, Noble and Rushton for their comments and helpful suggestions.

\section{References}

Aitchison, J. C. 1998. A Lower Ordovician (Arenig) radiolarian fauna from the Ballantrae Complex, Scotland. Scottish Journal of Geology 34, in press.

Aitchison, J. C. \& Murchey, B. L. 1992. (eds) Significance and application of Radiolaria to terrane analysis. Palaeogeography, Palaeoclimatology, Palaeoecology 96. Amsterdam: Elsevier, $174 \mathrm{pp}$.

Bengston, S. 1986. Siliceous microfossils from the Upper Cambrian of Queensland. Alcheringa 10, 195-216.

CAwood, P. A. \& SuHR, G. 1992. Generation and obduction of ophiolites: constraints from the Bay of Islands Complex, western Newfoundland. Tectonics 11, 884-97.

Church, W. R. \& Stevens, R. K. 1971. Early Paleozoic ophiolite complexes of the Newfoundland Appalachians as mantle-oceanic crust sequences. Journal of Geophysical Research 76, 1460-6.

Dong, X., Knoll, A. H. \& LIPPS, J. H. 1997. Late Cambrian Radiolaria from Hunan, China. Journal of Paleontology 71, 753-8.

EHRENBERG, C. G. 1838. Uber die Bildung der Kreidefelsen und des Kreidemergels durch unsichtbare Organismen. Konigliche Akademie der Wissenschaften zu Berlin, Abhandlungen 1838, 59-147.

Fortey, R. A. \& Holdsworth, B. K. 1971. The oldest known well-preserved Radiolaria. Bollettino della Societa Paleontologica Italiana 10, 35-41.

Harland, W. B., Armstrong, R. L., Cox, A. V., Craig, L. E., Smith, A. G. \& Smith, D. G. 1989. A geologic time-scale 1989. Cambridge: Cambridge University Press, 263 pp.

Holdsworth, B. K. \& Jones, D. L. 1980. Preliminary radiolarian zonation for late Devonian through Permian time. Geology 8, 281-5.

Iwata, K., Schmidt, B. L., Leitch, E. C., Allan, A. D. \& WatanaBe, T. 1995. Ordovician microfossils from the Ballast Formation (Giralambone Group) of New South Wales. Australian Journal of Earth Sciences 42, 371-6.

Jenner, G. A., Dunning, G. R., Malpas, J., Brown, M. \& BRACE, T. 1991. Bay of Islands and Little Port complexes, revisited: age, geochemical and isotopic evidence confirm suprasubduction-zone origin. Canadian Journal of Earth Science 28, 1635-52.

LI, H.-S. 1995. New genera and species of middle Ordovician Nassellaria and Albaillellaria from Bai-jingsi, Quilian Mountains, China. Scientia Geologica Sinica 4, 331-46.

Malpas, J. \& Stevens, R. K. 1977. The origin and emplacement of the ophiolite suite with examples from western Newfoundland. Geotectonics 11, 453-66.

MiLleR, J. F. 1988. Conodonts as biostratigraphic tools for redefinition and correlation of the Cambrian-Ordovician Boundary. Geological Magazine 125, 349-62.

MülleR, J. 1858. Uber die Thalassicollen, Polycystinen und Acanthometren des Mittelmeeres. Konigliche Preussische Akademie der Wissenschaften zu Berlin, Abhandlungen 1858, $1-62$.

NAZARov, B. B. 1973. Radiolyarii iz nizhnikh gorizontov krembriya Bazhenevskogo kryazha (Radiolaria from the lower horizons of the Cambrian of Bazhenev Ridge). In Problemy paleontologii $i$ biostratigrafii nizhnego kembriya Sibiri $i$ Dal'nego Vostoka Transactions of the Institute of Geology and Geophysics, vol. 49, pp. 5-13. Siberian Branch of the Academy of Sciences, Novosibirsk, USSR.

Nazarov, B. B. 1988. Radiolyarii Paleozoya. Prakticheskoe Rukovodstvo po Mikrofaune SSSR. Leningrad: Nedra, $232 \mathrm{pp}$.

Nazarov, B. B. \& Ormiston, A. R. 1984. Tentative system of 
Paleozoic Radiolaria. In Morphology, Ecology and Evolution of Radiolaria (ed. M. G. Petrushevskaya), pp. 64-87. Leningrad: Zoological Institute, Nauka.

NAzArov, B. B., Popov, L. \& Apollonov, M. 1975. Radiolyarii nizhnego paleozoya Kazakhstana (Lower Paleozoic Radiolaria in Kazahkstan). Izvestiya Akademiya Nauk SSSR, Seriya Geologicheskaya (Proceedings of the USSR Academy of Sciences, Geological Series) 10, 96-105.

NAZAROV, B. B. \& Popov, L. Y. 1980. Stratigraphy and fauna of the siliceous-carbonate sequence of the Ordovician of Kazakhstan (Radiolaria and inarticulate brachiopods). Trudy Geologicheskij Institut Academija Nauk S.S.S.R. 331, 1-182.

NiCOLL, R. S. 1990. The genus Cordylodus and a latest Cambrian-earliest Ordovician conodont biostratigraphy. Australian Bureau of Mineral Resources Journal of Australian Geology and Geophysics 11, 529-58.

NoBLE, P. J. 1994. Silurian radiolarian zonation for the Caballos novaculite, Marathon Uplift, West Texas. Bulletins of American Paleontology 106, 1-55.

Noble, P. J. \& Aitchison, J. C. 1995. Status of Ordovician and Silurian radiolarian studies in North America. In Siliceous Microfossils (eds C. D. Blome, P. M. Whalen and K. M. Reed), pp. 19-30. Short Courses in Paleontology no. 8. The Paleontological Society, University of Tennessee, Knoxville.

Pessagno, E. A. \& Newport, R. L. 1972. A technique for extracting Radiolaria from radiolarian cherts. Micropaleontology 18, 231-4.

RenZ, G. W. 1990a. Late Ordovician (Caradocian) radiolarians from Nevada. Micropaleontology 36, 367-77.

Renz, G. W. 1990b. Ordovician Radiolaria from Nevada and Newfoundland - a comparison at the family level. Marine Micropaleontology 15, 393-402.

Rushton, A. W. A., Stone, P., Smellie, J. L. \& Tunnicliff, S. P. 1986. An early Arenig age for the Pinbain sequence of the Ballantrae Complex. Scottish Journal of Geology 22, 41-54.

Stone, P. \& Rushton, A. W. A. 1983. Graptolite faunas from the Ballantrae ophiolite complex and their structural implications. Scottish Journal of Geology 19, 297-310.

Tucker, R. D. \& Mckerrow, W. S. 1995. Early Paleozoic chronology: a review in light of new $\mathrm{U}-\mathrm{Pb}$ zircon ages from Newfoundland and Britian. Canadian Journal of Earth Sciences 32, 368-79.

Umeda, M., Goto, H. \& Ishiga, H. 1992. Middle Ordovician radiolarians from the Lachlan Fold Belt, southeastern Australia. Memoirs of the Faculty of Science, Shimane University 26, 131-40.

WANG, Y. 1993. Middle Ordovician radiolarians from the Pingliang Formation of Gansu Province, China. In Radiolaria of giant and subgiant fields in Asia. Nazarov Memorial Volume (eds J. R. Blueford and B. L. Murchey), pp. 98-114. Micropaleontology Special Publication no. 6. New York, USA: American Museum of Natural History, Micropaleontology Press.

WebBy, B. D. \& BLom, W. 1986. The first well-preserved radiolarians from the Ordovician of Australia. Journal of Paleontology 60, 145-57.

White, R. D. 1986. Cambrian Radiolaria from Utah. Journal of Paleontology 60, 778-80.

WiLLIAMS, H. 1975. Structural succession, nomenclature, and interpretation of transported rocks in western Newfoundland. Canadian Journal of Earth Sciences 12, 1874-94.

Williams, H. \& Cawood, P. A. 1989. Geology, Humber Arm Allochthon, Newfoundland. Scale 1:250 000 Map 1678A. Geological Survey of Canada, Ottawa, Canada.

Williams, H. \& MalPas, J. 1972. Sheeted dikes and brecciated dike rocks within transported igneous complexes, Bay of Islands, western Newfoundland. Canadian Journal of Earth Sciences 9, 1216-29. 